\title{
A Statement from the Editors
}

This issue of AJS Review contains two new formats. The first is a symposium on the state of the field of Jewish book history, a set of brief contributions by three scholars from various chronological and disciplinary perspectives. The symposium was curated by Adam Shear, convener of an ongoing working group on that subject at the Center for Jewish History during the academic year 2009-10. The contributions reflect the authors' remarks in a live exchange and deliberately eschew the traditional heavy annotation of full-fledged scholarly articles.

A second innovation is an exchange of views prompted by the publication of David Myers' Between Jew and Arab. Book Review Editor Charlotte Fonrobert took a leading role in the formation of this exchange between Professors Gil Anidjar and David Myers on a topic of vital interest to scholars in Jewish studies on campuses world-wide. This issue also contains a review essay, a feature we plan to continue from time to time. The editors invite suggestions for other exchanges on topics in emerging fields or new turns of scholarship in traditional areas. We welcome ideas prompted by the publication of interesting, challenging, and significant new books in all fields of Jewish Studies.

Finally, the editors reiterate their appreciation to Mark Podwal for continuing to provide his wonderful illustrations for our cover.

Robert Goldenberg and Elisheva Carlebach, Editors

Charlotte Fonrobert, Book Review Editor 